\title{
Anti-hypercholesterolemia effects and quality of eel (Anguilla bicolor) oil
}

\author{
Heru Sasongko $^{1 *}$, Sugiyarto ${ }^{2}$, Agung Budiharjo $^{2}$ and Nur Rohman Efendi ${ }^{1}$ \\ ${ }^{1}$ Study program of Pharmacy, Faculty of Mathematics and Natural Sciences, Universitas \\ Sebelas Maret. J1. Ir. Sutami 36A Surakarta 57126, Central Java, INDONESIA
}

${ }^{2}$ Study program of Biology, Faculty of Mathematics and Natural Sciences, Universitas Sebelas Maret. J1. Ir. Sutami 36A Surakarta 57126, Central Java, INDONESIA

\section{E-mail: heru_sasongko@staff.uns.ac.id}

\begin{abstract}
Eel (Anguilla bicolor) is a general fish consumption in many countries. Besides its vitamin rich, eel oil is also known to contain fatty acids like oleic acid and palmitic acid. That is necessary for traditional medicine and as food a supplement. It is known that polyunsaturated fatty acids are recognized to lower blood cholesterol. In this study, fresh eels were extracted using reflux methods. The study was conducted on rat test animals given high-fat diet and PTU (Propylthiouracil). Treatment was given eel fish oil with dose $0.5 \mathrm{ml} / \mathrm{kg} \mathrm{BW} ; 1 \mathrm{ml}$ $/ \mathrm{KgBW}$ and $2 \mathrm{ml} / \mathrm{KgBW}$. The results of eel extraction showed that the metal content is undetectable except $\mathrm{Zn}$ metal $11.72 \mathrm{ppm}$. Eel fish oil affects the total cholesterol decrease at each dose $(\mathrm{h}<0.05)$. Known percent increase in total cholesterol after 14 days at a dose of $0.5 \mathrm{ml} / \mathrm{kg}$ body weight $(-14.10 \%) ; 1 \mathrm{ml} / \mathrm{kg}$ BW $(2.12 \%)$ and $2 \mathrm{ml} / \mathrm{kg} \mathrm{BW}(11.37 \%)$.
\end{abstract}

Keyword : Anguilla bicolor, Anti-hypercholesterolemia, oil, quality

\section{Introduction}

Indonesia is one of the countries that have a diversity of fish because of the vast ocean resources. There are about 20,000 species of fish in the world where 8,500 species live in Indonesia. Eel fish is one of the consumption fish which of the 19 species of eel in the world, nine species of which live in the waters of Indonesia. Anguilla bicolor is a very abundant eel in Indonesia [1]. Eel fish oil is known to contain vitamins, proteins, saturated fatty acids (SFA), monounsaturated fatty acids (MUFA), polyunsaturated fatty acids (PUFAs) [2], [3]. The contents of crude lipids were Anguilla bicolor is $10.5 \%$ [2], [4]. In addition to fatty eel fish also found in almost all fish [5], [6].

The fatty acids composition of fresh Indonesian Eels consisted of 32.84\% MUFA, $22.78 \%$ SFA, $11.4 \%$ PUFA, $1.15 \%$ eicosapentaenoic acid (EPA) and $5.16 \%$ docosahexaenoic acid (DHA) [2]. Many studies have reported that fatty acids in the diet affect blood fat constituent [7], [8] which then result in cardiovascular disease [9], [10]. Dyslipidemia results from increased cholesterol and triglycerides above normal values. Increased serum cholesterol occurs an increase in LDL cholesterol (Low-Density Lipoprotein) primarily. Low-Density Lipoprotein which has the highest cholesterol 
content than other lipoproteins. The presence of LDL may induce the formation of atherosclerosis [11]. It was known that polyunsaturated fatty acids (PUFAs) including oleic acid and palmitic acid affect blood lipids, especially cholesterol, LDL-cholesterol, and triglycerides [12]. The higher dose of EPA+DHA lowered triglycerides by $27 \%$ compared with placebo [13].

\section{Materials and methods}

\subsection{Materials}

Materials used in this study include eel fish (Anguilla bicolor), white male rats Sprague Dawley, propylthiouracil / PTU (Kimia Farma $\left.{ }^{\circledR}\right)$, quail eggs, simvastatin (Kimia Farma ${ }^{\circledR}$ ), reflux equipment, centrifugation (Hitachi Himac CR 21G) and as a GCU tool fauna test equipment.

\subsection{Oil extractions}

The total of $2 \mathrm{Kg}$ fresh eel fish first washed and removed dirt, then chopped to form small pieces. The material that has become a small piece is then washed again with running water. Pieces of clean eels are then extracted by reflux method using Aqua dest solvent at $100{ }^{\circ} \mathrm{C}$ for 5 hours. The extract was then filtered using gauze and taken up the top layer (oil) then at centrifuge 3,000 rpm. Separate from impurities, results of flight as eel oil. The filtered eels are refluxed to ensure the oil is removed [14].

\subsection{Quality identification of eel oil}

Parameters of oil content tested were metal content such as $\mathrm{Pb}, \mathrm{Cd}, \mathrm{Sn}, \mathrm{Hg}, \mathrm{As}, \mathrm{Cu}$, Fe, and Zn by ICP-OES method and AAS.

\subsection{Preparation of test animals}

This study was conducted using Sprague-Dawley male, white rats. Before testing, the test animals were first adapted to the test environment conditions for one week. The test animals were randomly divided into six groups with five replication in each group. The G1 is a normal group given only standard feed and drink. The G2 is a positive control where the test animals are fed, drink standard, egg yolk induction, and given simvastatin $10 \mathrm{mg} / \mathrm{kg} \mathrm{BW}$. The G3 is a negative control where the test animals are fed, standard drink, egg yolk induction, no active substance. The G4 is animal test Fed feeding, standard drinking, egg yolk induction, and $0.5 \mathrm{~mL} / \mathrm{Kg}$ BW eels oil every day. The G5 is tested animals fed, standard drink, egg yolk induction, and one $\mathrm{mL} / \mathrm{Kg} \mathrm{BW}$ eels oil every day. The G6 is tested animals fed, standard drink, Egg yolk induction, and given two $\mathrm{mL} / \mathrm{Kg} \mathrm{BW}$ eels oil every day.

\subsection{Determination of doses of simvastatin and PTU}

The test animals were weighed first to determine the appropriate dosage for simvastatin administration in positive control and PTU administration in all treatment 
groups. The dose of simvastatin is given $10 \mathrm{mg} / \mathrm{kg}$ BW with administration once daily. PTU was administered to test animals at a dose of $12.5 \mathrm{mg} / \mathrm{ml}$ induced with a volume of $2.5 \mathrm{ml}$ on days 1 and 7 .

\subsection{Increased cholesterol levels}

To increase the cholesterol levels of mice in the test animals was done $2 \mathrm{ml}$ quail egg-induced twice daily in the morning and afternoon from day 1 to day 14 . In addition to egg yolk induced to increase cholesterol in the test, animals were also given chicken feed as much as broiler 15 grams per animal in a day.

\subsection{Test decrease cholesterol levels}

The test animals were administered according to the test specimen and the specified eel oil dose. Treatments were administered for 14 days and then tested the cholesterol levels of test animals on days 1, 7, and 14 using the GCU test. Before cholesterol levels are measured, the first rat is satisfied for 10-12 hours. Before measurement, the tool was first calibrated by adjusting the code number on the test strip. The test strips are placed on the GCU test kit and the screen; the "drops blood" image will show the device is ready for use. Blood sampling was performed on rats' tail that had previously been disinfected with $70 \%$ ethanol. The first drop of blood is removed when the next drop of blood drops on the test strip. A certain amount of blood will be absorbed according to the absorption capacity of the test strip until the audible beeps are heard. Results will be seen on screen after 150 seconds for cholesterol test [15].

\section{Result and discussion}

The results of quality parameters of eel fish oil extract were shown in Table 1.

Table 1. Eel fish oil content and the quality parameters

\begin{tabular}{ccccc}
\hline Parameters & Result & Unit & $\begin{array}{c}\text { Limite of } \\
\text { detection }\end{array}$ & Method \\
\hline $\mathbf{P b}$ & Not detected & Ppm & 0.009 & ICP-OES \\
$\mathbf{C d}$ & Not detected & Ppm & 0.00011 & ICP-OES \\
$\mathbf{S n}$ & Not detected & Ppm & 0.45 & ICP-OES \\
$\mathbf{H g}$ & Not detected & Ppm & 0.004 & ICP-OES \\
$\mathbf{A s}$ & Not detected & Ppm & 0.008 & ICP-OES \\
$\mathbf{C u}$ & Not detected & $\mathrm{ppm}$ & 0.005 & AAS \\
$\mathbf{F e}$ & Not detected & $\mathrm{ppm}$ & 0.001 & AAS \\
$\mathbf{Z n}$ & 11.72 & $\mathrm{ppm}$ & - & AAS \\
\hline
\end{tabular}

The test of some metals shows no detectable. Prolonged exposure to metals such as $\mathrm{Pb}, \mathrm{Cd}, \mathrm{Sn}, \mathrm{Hg}$, As and $\mathrm{Cu}$ can cause health effects in humans [16], [17]. Some metals such as Cd may interfere with antioxidant action in the body [18]. Zn content detected for $11.72 \mathrm{ppm}$ indicates the presence of eel oil that still contains minerals that the body needs. Zn metals in the body are needed in certain amounts for the body, antioxidants, 
anti-inflammation against diarrhea [19], [20]. The results of total cholesterol testing for 14 days can be seen in Table 2 below:

Table 2. Testing cholesterol levels in test animals for 14 days

\begin{tabular}{llll}
\hline \multirow{2}{*}{ Group } & \multicolumn{3}{c}{ Cholesterol levels (mg/dl) } \\
\cline { 2 - 4 } & \multicolumn{1}{c}{ D0 } & \multicolumn{1}{c}{ D7 } & \multicolumn{1}{c}{ D14 } \\
\hline Normal controls (G1) & $147.75 \pm 10.34$ & $148.5 \pm 43.10$ & $147.5 \pm 36.35$ \\
Positive controls (G2) & $126.75 \pm 12.04$ & $170 \pm 61.10$ & $150.75 \pm 14.00$ \\
Negative controls (G3) & $127 \pm 22.18$ & $201 \pm 119.80$ & $222.25 \pm 117.61$ \\
Eel oil 0.5 mL/Kg BW (G4) & $152.5 \pm 31.03$ & $199 \pm 67.24$ & $131 \pm 21.06$ \\
Eel oil 1 mL/Kg BW (G5) & $141.25 \pm 15.76$ & $204.75 \pm 80.38$ & $144.25 \pm 15.97$ \\
Eel oil 2 mL/Kg BW (G6) & $140.75 \pm 20.69$ & $169 \pm 38.18$ & $156.75 \pm 36.07$ \\
\hline
\end{tabular}

Table 2 shows that the range of cholesterol levels before treatment (H0) of all treatment groups was $126.75-152.5 \mathrm{mg} / \mathrm{dl}$. In the normal group without treatment, the only standard feed was found to have the same cholesterol levels for 14 days 147.5 $\mathrm{mg} / \mathrm{dl}$. This shows that cholesterol levels in the normal group are in the range 126.75 $152.5 \mathrm{mg} / \mathrm{dl}$. On the positive controls given simvastatin drugs showed an increase in cholesterol levels on day 7 and on day 14 there was a decrease again. This suggests that simvastatin which is an anti hyper cholesterol drug can lower cholesterol [21]. Normal and positive control groups showed different cholesterol levels when compared with negative controls. This proves that the test method is valid. From the data table 2, can be calculated percentage increase in cholesterol levels that can be seen in Table 3.

Table 3. Percent increase in cholesterol levels for seven days and 14 days

\begin{tabular}{lcc}
\hline Group & Percent increase in cholesterol levels (\%) \\
\hline Normal controls (G1) & D7 & D14 \\
Positive controls (G2) & 0.51 & -0.17 \\
Negative controls (G3) & 34.12 & 18.93 \\
Eel oil 0.5 mL/Kg BW (G4) & 58.27 & 75.00 \\
Eel oil 1 mL/Kg BW (G5) & 30.49 & -14.10 \\
Eel oil 2 mL/Kg BW (G6) & 44.96 & 2.12 \\
\hline
\end{tabular}

From Table 3 can be seen with the value of eel fish oil give a percent yield increase of different cholesterol levels from each group. In normal control, there was virtually no significant decrease for 14 days. It is because, for 14 days, test animals were only given standard feed. The negative control group showed the highest increase of cholesterol level compared to other groups that are $75 \%$. It is because the negative control group was given only high-fat diet and PTU. While in the positive control and treatment with doses of eel fish oil showed a percentage increase in cholesterol levels far below 
negative controls. It indicates the presence of eel fish oil and simvastatin affect the decrease of total cholesterol in animal test. Giving at a dose of $0.5 \mathrm{ml} / \mathrm{KgBB}$ showed the best results of the test results for 14 days. Oleic acid can lower total cholesterol, VLDL-, and LDL levels with LDL receptors and increased CETP (plasma cholesteryl ester transfer protein) activity [22]. In experimental and animal models, both EPA and DHA modulate several relevant biologic pathways, with evidence for some differential benefits. In humans, both fatty acids lower TG levels. PUFA reduce ex vivo platelet aggregation and DHA also modestly increases LDL and HDL particle size [23].

\section{Conclusion}

The metal content is undetectable except $\mathrm{Zn}$ metal $11.72 \mathrm{ppm}$ on eel oil. Eel fish oil affects the total cholesterol decrease at each dose $(\mathrm{h}<0.05)$. Known percent increase in total cholesterol after 14 days at a dose of $0.5 \mathrm{ml} / \mathrm{kg}$ body weight $(-14.10 \%) ; 1 \mathrm{ml} / \mathrm{kg}$ BW (2.12\%) and $2 \mathrm{ml} / \mathrm{kg} \mathrm{BW}(11.37 \%)$. Need more in-depth testing of more specific cholesterol parameters such as LDL, HDL, VLDL, and TG

\section{Acknowledgments}

Universitas Sebelas Maret financed this study with schemes Pusat Unggulan PNBP UNS.

\section{Conflicts of Interest}

The authors declare no conflict of interest

\section{References}

[1] A. BUDIHARJO, "DARI HULU KE HILIR, DARI RISET KE INDUSTRI, DARI SIDAT KE UNAGI," Pros. Semin. Nas. Biodiversitas Vol 5 No 12016.

[2] C. M. Kusharto, R. A. H. E. Widyasari, Budywiryawan, E. S. Wiyono, and Sugengherisuseno, "Nutritive Value and Fatty Acids Profile of Fresh Indonesian Eel (Anguilla bicolor) and Kabayaki," J. Sains Kesihat. Malays. Malays. J. Health Sci., vol. 12, no. 1, Jun. 2014.

[3] A. A. B. Putri, Y. Yuliet, and J. Jamaluddin, "ANALISIS KADAR ALBUMIN IKAN SIDAT (Anguilla marmorata dan Anguilla bicolor) DAN UJI AKTIVITAS PENYEMBUHAN LUKA TERBUKA PADA KELINCI (Oryctolagus cuniculus)," J. Farm. Galen. Galen. J. Pharm., vol. 2, no. 2, pp. 90-95, Oct. 2016.

[4] J. C. Ahn et al., "An Evaluation of Major Nutrients of Four Farmed Freshwater Eel Species (Anguilla japonica, A. rostrata, A. bicolor pacifica and A. marmorata)," Korean J. Fish. Aquat. Sci., vol. 48, no. 1, pp. 44-50, 2015.

[5] W. Steffens, "Effects of variation in essential fatty acids in fish feeds on nutritive value of freshwater fish for humans," Aquaculture, vol. 151, no. 1, pp. 97-119, May 1997.

[6] M. V. Bell, R. J. Henderson, and J. R. Sargent, "The role of polyunsaturated fatty 
acids in fish," Comp. Biochem. Physiol. Part B Comp. Biochem., vol. 83, no. 4, pp. 711-719, Jan. 1986.

[7] C. L. Chang, C. Torrejon, U. J. Jung, K. Graf, and R. J. Deckelbaum, "Incremental replacement of saturated fats by $\mathrm{n}-3$ fatty acids in high-fat, highcholesterol diets reduces elevated plasma lipid levels and arterial lipoprotein lipase, macrophages and atherosclerosis in LDLR-/- mice," Atherosclerosis, vol. 234, no. 2, pp. 401-409, Jun. 2014.

[8] F. H. Mattson and S. M. Grundy, "Comparison of effects of dietary saturated, monounsaturated, and polyunsaturated fatty acids on plasma lipids and lipoproteins in man.," J. Lipid Res., vol. 26, no. 2, pp. 194-202, Feb. 1985.

[9] L. Schwingshackl and G. Hoffmann, "Monounsaturated fatty acids, olive oil and health status: a systematic review and meta-analysis of cohort studies," Lipids Health Dis., vol. 13, p. 154, Oct. 2014.

[10] Chowdhury R, Warnakula S, Kunutsor S, and et al, "Association of dietary, circulating, and supplement fatty acids with coronary risk: A systematic review and meta-analysis," Ann. Intern. Med., vol. 160, no. 6, pp. 398-406, Mar. 2014.

[11] J. Anbu, K. Anjana, K. Purushothaman, M. Sumithra, S. Suganya, and N. Bathula, "Evaluation Ofantihyperlipidemic Activity Of Ethanolic Extract Of Saussurae Lappa In Rats," Int J Pharma Bio Sci, vol. 2, no. 4, pp. 550-556, 2011.

[12] E. Lopez-Huertas, "Health effects of oleic acid and long chain omega-3 fatty acids (EPA and DHA) enriched milks. A review of intervention studies," Pharmacol. Res., vol. 61, no. 3, pp. 200-207, Mar. 2010.

[13] A. C. Skulas-Ray, P. M. Kris-Etherton, W. S. Harris, J. P. V. Heuvel, P. R. Wagner, and S. G. West, "Dose-response effects of omega-3 fatty acids on triglycerides, inflammation, and endothelial function in healthy persons with moderate hypertriglyceridemia," Am. J. Clin. Nutr., vol. 93, no. 2, pp. 243252, Feb. 2011.

[14] H. Sasongko et al., "Solvent and extraction methods effects on the quality of eel ( Anguilla bicolor ) oil," J. Phys. Conf. Ser., vol. 795, no. 1, p. 12021, 2017.

[15] S. R. Umami, S. S. Hapizah, R. Fitri, and A. Hakim, "UJI PENURUNAN KOLESTEROL PADA MENCIT PUTIH (Mus musculus) SECARA IN-VIVO MENGGUNAKAN EKSTRAK METANOL UMBI TALAS (Colocasia esculenta L) SEBAGAI UPAYA PENCEGAHAN CARDIOVASCULAR DISEASE," J. PIJAR MIPA, vol. 11, no. 2, Sep. 2016.

[16] L. R. Bordajandi et al., "Survey of Persistent Organochlorine Contaminants (PCBs, PCDD/Fs, and PAHs), Heavy Metals ( $\mathrm{Cu}, \mathrm{Cd}, \mathrm{Zn}, \mathrm{Pb}$, and $\mathrm{Hg}$ ), and Arsenic in Food Samples From Huelva (Spain): Levels and Health Implications," J. Agric. Food Chem., vol. 52, no. 4, pp. 992-1001, Feb. 2004.

[17] R. Singh, N. Gautam, A. Mishra, and R. Gupta, "Heavy metals and living systems: An overview," Indian J. Pharmacol., vol. 43, no. 3, pp. 246-253, 2011.

[18] A. Eroglu, Z. Dogan, E. G. Kanak, G. Atli, and M. Canli, "Effects of heavy metals 
(Cd, $\mathrm{Cu}, \mathrm{Cr}, \mathrm{Pb}, \mathrm{Zn})$ on fish glutathione metabolism," Environ. Sci. Pollut. Res., vol. 22, no. 5, pp. 3229-3237, Mar. 2015.

[19] A. S. Prasad, "Zinc is an Antioxidant and Anti-Inflammatory Agent: Its Role in Human Health," Front. Nutr., vol. 1, Sep. 2014.

[20] A. S. Prasad, "Impact of the discovery of human zinc deficiency on health," $J$. Trace Elem. Med. Biol., vol. 28, no. 4, pp. 357-363, Oct. 2014.

[21] C. Baigent et al., "The effects of lowering LDL cholesterol with simvastatin plus ezetimibe in patients with chronic kidney disease (Study of Heart and Renal Protection): a randomised placebo-controlled trial," The Lancet, vol. 377, no. 9784, pp. 2181-2192, Jun. 2011.

[22] K. Hitoshi et al., "Opposite effects on cholesterol metabolism and their mechanisms induced by dietary oleic acid and palmitic acid in hamsters," Biochim. Biophys. Acta BBA - Lipids Lipid Metab., vol. 1258, no. 3, pp. 251256, Oct. 1995.

[23] D. Mozaffarian and J. H. Y. Wu, "(n-3) Fatty Acids and Cardiovascular Health: Are Effects of EPA and DHA Shared or Complementary?," J. Nutr., vol. 142, no. 3, p. 614S-625S, Mar. 2012. 